Article

\title{
Student's Knowledge, Attitude, and Perception (KAP) to Solid Waste Management: A Survey towards a More Circular Economy from a Rural-Based Tertiary Institution in South Africa
}

\author{
Oluwatobi Mary Owojori ${ }^{1, * \mathbb{D}}$, Ratshalingwa Mulaudzi ${ }^{1}$ and Joshua N. Edokpayi $^{2}$ (D) \\ 1 Department of Ecology and Resources Management, School of Environmental Sciences, University of Venda, \\ Thohoyandou 0950, South Africa; ratshalingwa.mulaudzi@univen.ac.za \\ 2 Department of Hydrology and Water Resources, School of Environmental Sciences, University of Venda, \\ Thohoyandou 0950, South Africa; Joshua.Edokpayi@univen.ac.za \\ * Correspondence: tobiowojori@gmail.com
}

check for

updates

Citation: Owojori, O.M.; Mulaudzi,

R.; Edokpayi, J.N. Student's

Knowledge, Attitude, and Perception (KAP) to Solid Waste Management: A Survey towards a More Circular Economy from a Rural-Based Tertiary Institution in South Africa.

Sustainability 2022, 14, 1310. https:/ / doi.org/10.3390/su14031310

Academic Editor: Luis Jesús

Belmonte-Ureña

Received: 9 December 2021

Accepted: 18 January 2022

Published: 24 January 2022

Publisher's Note: MDPI stays neutral with regard to jurisdictional claims in published maps and institutional affiliations.

Copyright: (c) 2022 by the authors. Licensee MDPI, Basel, Switzerland. This article is an open access article distributed under the terms and conditions of the Creative Commons Attribution (CC BY) license (https:// creativecommons.org/licenses/by/ $4.0 /)$.

\begin{abstract}
Students of Higher Educational institutions (HEIs) are regarded as major stakeholders of an institution and key agents of transformation in society. Thus, the environmental knowledge of students in academic institutions is instrumental in providing a solution to the solid waste menace and other environmental problems in the community. However, there exists a wide rural-urban gap in transitioning towards sustainable development across HEIs. This informed the current study examining the knowledge, attitude, and perception (KAP) of students at a rural-based educational institution on solid waste management. It also aimed to learn about the institution's current practices regarding solid waste management and identify steps that can be taken to move the institution closer to a circular economy goal. This study presents the KAP results from a survey of 376 students from nine schools at the University of Venda for the conceptualization of a circular economy (CE) vision for the university. The results show that the knowledge of the students on solid waste management was low and inadequate. However, students are willing to partake in recycling projects to improve the current environmental state of the institution. This study also revealed that some of the students $(41 \%)$ require motivation to participate in recycling schemes through economic incentives. Increasing awareness of environmental education and initiating participatory environmental programs and strengthening 3 of the key sustainability competencies is recommended as an effective tool to transition to a circular economy in the institution. Further studies are recommended in areas of gamified learning for $\mathrm{CE}$ and capital generation from waste for capacity building.
\end{abstract}

Keywords: attitude; knowledge; perception; student; recycling; solid waste; higher education; youths; circular economy

\section{Introduction}

The transition to a circular economy represents a promising passage to sustainable development, which stems from the right knowledge, attitude, and perception of higher educational institutions, as they are regarded as the frontiers and carriers of knowledge that trickles down to the community at large. The role of students in higher institutions of learning cannot be exaggerated, as it is recognized as pivotal in contributing towards the circularity and sustainable development of a nation. This is also acknowledged nationally in South Africa's National Youth policy, which declared that youths represent major agents of social transformation, economic growth, and invention. Their resourcefulness, inspiration, vigor, and vision are recognized to be highly imperative for a country's development [1].

The awareness of the abovementioned has triggered the establishment of several initiatives that are being targeted at the youth, aiming at their inclusiveness in sustainable development, among which is the right knowledge of solid waste management among 
university students. The management of solid waste is a socio-environmental concern with far-reaching consequences if mismanaged. This has required organizations and educational institutions to consider it as a very important issue. It has been argued that the human activities carried out in workshops, laboratories, etc., within a tertiary institution could pose a threat to the environment if not properly managed [2].

One major way of reducing the environmental impact of solid waste generation is through the application of the reduce, re-use, recycle and recover principles as a subset of the circular economy [3]. Therefore, special attention is required from educational institutions, especially tertiary institutions, in shaping students' attitudes and perceptions. Attitudes and perceptions inform students' environmental behavior, and as such, it is crucial to appraise the environmental awareness level of students in solid waste management in academic institutions [4]. The environment suffers from diverse environmental problems that require an individualistic approach, requiring each person to develop the right attitudes that will direct them towards environmentally sustainable behavior [5]. Velazquez et al. [6] defined a sustainable university as an "educational institute of learning, which compositely or partly addresses, engages and fosters, locally or globally, the reduction of adverse environmental, economic, societal, and health impacts generated in the utilization of resources to fulfill the primary functions of teaching, research, outreach and partnership, and learning in ways to help society make the transition to sustainable lifestyles".

To ensure a sustainable environment, there is a need to protect, conserve and manage the environment sustainably through environmental education and awareness [7]. Environmental education is a procedure planned for building up citizens to know and be concerned about their environment's condition and its related problems. This informs them of the responsibility to work exclusively towards more sustainable development. The essence of achieving environmental sustainability in higher institutions of learning cannot be overemphasized and has been highlighted by many researchers $[2,6,8]$. Universities, similarly to cities, engage in complex activities and interactions that are associated with potentially significant environmental impacts, which, until recently, have not received attention in terms of social and environmental responsibility [9].

This study considers South African youth, defined in South Africa as people in the age category of 14 to 35 years [1], particularly the student population at higher educational institutions, for two significant reasons. On one hand, the youth population, including those who are actively registered as students in tertiary institutions (aged 18-34), makes up close to a third of the overall South African population [10]. On the other hand, in South Africa, nearly $13 \%$ of the youth in the age bracket 20-34 are graduates [10]. Furthermore, at the national level, the South African government and the department of higher education are highly committed to adapting to a circular economy, with emphasis on efforts to develop students' potential as a change agent through the operation of youth-related policies, training, and programs associated with sustainable environmental development [11].

However, at the provincial level, the rural provinces are disadvantaged, with considerably lower numbers of students. This is largely determined by several factors, such as migration and inter-provincial patterns that significantly impact the structure and population of the provinces in South Africa.

Figure 1 shows the distribution of the South Africa population across different age groups, with the youth population being the highest.

Students are an important agent for sustainable development [12] and the time has come to harness their potential as a change agent without hesitation [13]. One of the institutions capable of promoting awareness of solid waste management in the community is the university. The time is now to put students at the focal point of environmental education. Institutions must realize that the solution lies in harnessing and utilizing waste as a useful resource, rather than an item to be destroyed [14]. 


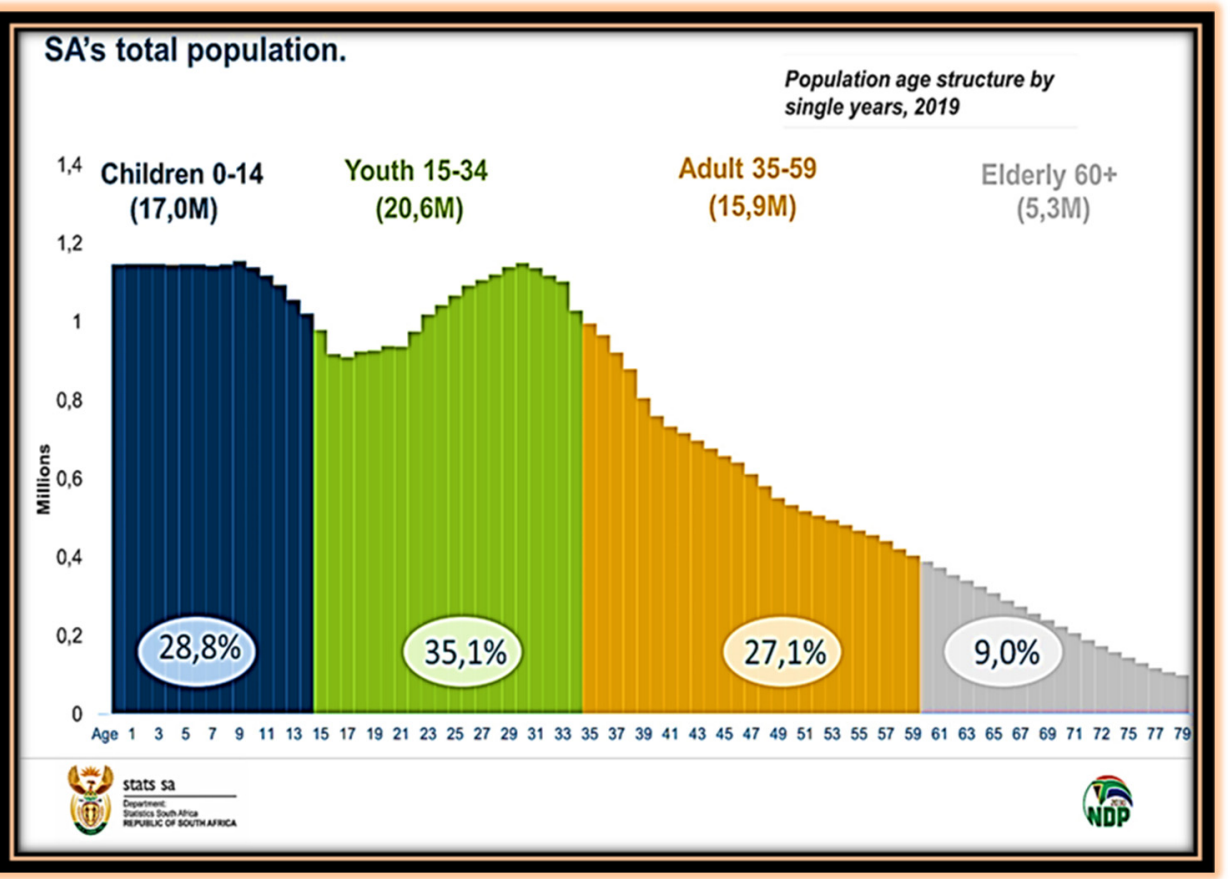

Figure 1. Population by age structure distribution in South Africa (source: adapted from Stats SA, 2019).

Following the UN's Sustainable Development Goals (SDGs), which necessitate that all students across all institutions of learning acquire the knowledge required to promote sustainable development by the year 2030, educational institutions globally have been responding to what is required. However, there is a wide rural-urban gap across educational institutions in their pathways to sustainable development, as transitioning to a more circular economy in rural areas poses a huge challenge.

Considering the context of rural areas, with their peculiar socioeconomic status, geography, cultures, populations and other variables [15], there has been little research on, or even a neglect of, environmental education among students of higher educational institutions in developing nations, and particularly those from rural institutions. This has led to criticism by some researchers critiquing educational institutions for producing graduates of inadequate capacity to function and address the growing environmental problems facing mankind [16]. Despite the importance of university campuses in promoting environmental sustainability, few studies have explored the concept of environmental sustainability from the perspective of students in higher educational institutions, especially in the rural global south; therefore, this study attempts to fill this gap using the University of Venda students in the rural province of Limpopo as a case study. The literature in South Africa on the perceptions of people towards solid waste has been limited to household and municipal waste. The perceptions of students in educational institutions are scarcely discussed and skewed towards tertiary institutions in urban areas; currently, there is no research on the assessment of the knowledge, attitude, and perception (KAP) of students in an indigenous institution such as the University of Venda, making this study a necessity. Inferring from the literature, it is imperative to develop solid waste management awareness in educational institutions, hence our argument for increased education on sustainable development.

This paper examines the knowledge, attitude, and perception (KAP) of students at a rural-based educational institution in relation to solid waste management. It also aims to learn about the institution's current practices regarding solid waste management and identify steps that can be taken to move the institution closer to a circular economy. 


\subsection{Contribution of the Study}

This study thus contributes to the ongoing discourse on sustainability in higher educational institutions by providing the results of a survey from the lens of students in a rural setting. It is envisaged that this will provide a basis for understanding the characteristics and differing perspectives of this community type, and thus a reference for other rural-based tertiary institutions. There is a need for a better understanding of the intricacy of the efforts required in the adoption of CE strategies in rural communities.

It is on this premise that this study seeks to survey the discourse, building on the knowledge of previous studies to examine the knowledge, attitude, and perception (KAP) of students at a rural-based educational institution (University of Venda) in relation to solid waste management. It also aims to learn about the institution's current practices regarding solid waste management and identify steps that can be taken to move the institution closer to a circular economy. It is believed that the survey from this group of students, focusing on their local, geographical, and cultural context, will also foster inclusivity in sustainable development and reduce the rural-urban gap in institutional sustainable development globally.

Taking into consideration the above paragraphs, this study seeks to answer the following research questions (RQ):

RQ1. What are the current knowledge, attitudes, and perceptions of these groups of students regarding solid waste management?

RQ2. What constitutes their current practices regarding solid waste management?

RQ3. What steps can be taken towards a circular economy vision in the institution?

\subsection{Structure of the Paper}

The rest of the study is organized as follows; the next Section 2 presents a literature review on education for sustainable development, sustainable development competencies, and the circular economy framework. Section 3 describes the methodology for the survey, Section 4 presents the results of the findings and a discussion of the survey on the student's knowledge, attitudes, and perceptions of littering and Solid Waste Management, and Section 5 gives the conclusions of the study and suggests areas for further research.

\section{Research Background and Literature Review}

\subsection{A Trajectory of the Concepts of Environmental Education and Education for} Sustainable Development

Environmental education is a continual process in which individuals and communities become conscious of their environment and develop the values, skills, and desires to act in order to address existing and future environmental problems [17].

Early environmental education aimed at making students aware of damages to the environment and teaching them to better conserve the environment, based on the United Nations Environmental Scientific and Cultural Organization (UNESCO) and the United Nations Environment Program (UNEP), which encouraged this education through the Belgrade Charter (UNEP) of 1975. The Charter established educational principles to help students gain a fundamental grasp of ecology, the natural environment and its current state, the need to protect nature, and the skills required to help address environmental concerns [18]. After the Belgrade Charter, in 1977, the Tbilisi Declaration, backed by UNESCO and UNEP, established more defined goals, objectives, and guiding principles for environmental education, focusing on environmental sustainability.

About ten years afterward, however, the growth report showed escalating human population growth and increased consumption, and thus there was a shift in education toward sustainable development. Education for Sustainable Development (ESD) was developed based on the Brundtland Report published by the World Commission on Environment and Development in 1987 [19]. In 2002, the United Nations General Assembly passed Resolution 57/254, designating the years 2005-2014 as the UN Decade of Education for Sustainable Development. The UN Decade of Education for Sustainable Development 
(DESD), which ran from 2005 to 2014, put a greater emphasis on the social and economic components of sustainability [20]. The DESD was then followed by Education for Sustainable Development Goals (ESDG), which was inspired by the UN's SDGs in 2015 [21]. The fourth objective of the SDGs, "Quality Education", states that every student should gain the information and skills needed to facilitate sustainable development.

Education for Sustainability development (ESD) aims to empower people to make informed decisions and act responsibly to conserve the environment, promote a more ecosocial economy, and build a just society for current and future generations while respecting cultural diversity. The era also saw a rise in political interest in creating opportunities for social stakeholders to engage in favor of sustainable development. As a result of the increased political interest, worldwide initiatives, such as the UNECE Strategy for Education for Sustainable Development [22], launched in 2005, was transitioned into the UN Global Action Program (GAP) on Education for Sustainable Development (2015-2019) [23]. The advent of the 17 SDGs and the declaration of Agenda 2030 at the 2015 United Nations Climate Summit enabled the principles of the Decade of Education for Sustainable Development to be explicitly stated, concretized, and internationally conveyed [24]. In 2020, the roadmap was more closely integrated with Agenda 2030's objective dimensions and needs, as well as the 17 SDGs under the broad theme of Education 2030 [25].

Furthermore, the notions of ESD and EE are no longer regarded to be equal or similar, and the link between them is progressively being minimized [26]. Some countries advocate for separation, while others advocate for a merger of EE and ESD [27]. The Thessaloniki Declaration proposed in 1997 that "environmental education be referred to as education for the environment and sustainability" [28], creating "a framework for education for sustainability while neutralizing the term environmental education" [29]. This assessment explains why EE's orientation is in jeopardy, and issues an awakening call to the EE professionals to keep the field from being swallowed by a rather more liberal movement.

However, EE and ESD discourse and application are widespread and uncontroversial in the Southern African region, especially among environmental academics and researchers. ESD is acknowledged as a distinct concept here, articulating themes that have been debated since the establishment of the Environmental Education Association of Southern Africa in 1982 [30].

Education and sustainable development are two distinct topics of interest to many stakeholders, and ESD has its origins in the history of both. ESD is founded on the concepts and values that underpin sustainable development by guaranteeing the well-being of the five pillars of sustainability, which include the environment, people, economy, stability, and cooperation [30]. It is a multidimensional construct and term that encompasses a revolutionary vision of education that aims to empower individuals of all ages to assume responsibility for ensuring a sustainable future [31]. The ESD for 2030 framework defines actions in five strategic action areas: policy, learning environments, educator capacity building, youth, and local level action, emphasizing ESD's critical role in achieving the 17 SDGs and the massive individual and societal transformation required to address the world's most pressing sustainability challenges.

The UN 2030 Global Agenda for Sustainable Development must be localized to meet the needs and expectations of local communities [32]. This is a critical step since achieving systemic transformation toward sustainable development by 2030 and beyond would involve collective action, and multi-stakeholder collaboration among students, professors, management, as well as external players such as local governments and communities, for the visioning process [33].

\subsection{Overview on Knowledge, Attitude, and Perception (KAP) Regarding Solid Waste Management}

The term knowledge, attitude, and perception (KAP) was first used in a survey in the 1950s to investigate how the idea of birth prevention or planned parenthood was accepted, perceived, and practiced across different populations globally [34]. The elementary principles of the KAP surveys are that knowledge shapes the attitude and that both knowledge 
and attitude are the elementary units for practice. KAP studies are employed for three broad uses: as an analytical instrument to report people's present knowledge, attitude and practice; to offer understandings of a present condition for planning explicit interventions, and as an instrument for appraising the efficacy of certain interventions or initiatives [35].

Knowledge is critical as a major determinant in developing behavioral intentions and attitudes [36]. The knowledge of students of littering and proper waste management is related to the capacity to accept ideas and behavioral patterns related to environmental sustainability. Increased knowledge in this aspect will enhance the student's awareness and attitudes toward the environment [37]. The attitudes of students, on the other hand, could influence certain subjective norms, which translate into behavioral patterns. Attitude is found to be a fundamental driver of a student's behavior because it controls how the students will respond to the waste management concerns, and this influences their proenvironmental behavior in acting beneficially towards the environment [38].

Perception also plays a vital role in the behavioral intention of the students; it is found that a high level of perceived knowledge encourages students to change their behavior towards waste management and the environment [39]. Similar to knowledge, perception informed the student's intentions to behave in a certain way towards the environment and management of waste, and their level of knowledge also translates into right or inappropriate intentions, which also leads to right or inappropriate actions or behaviors.

KAP surveys have been broadly utilized to investigate human behavior in diverse fields such as public development [40], ecological awareness, [41] water, sanitation, and hygiene [42]. The surveys, universally, are very well-acknowledged as a concrete framework to measure people's understanding, consciousness, inclination, and participation in relation to particular subjects [35,36].

Previous studies have sought to understand the knowledge, attitude, and perception (KAP) of students regarding solid waste and how this influences their environmental behavior. For example, Singh et al. [43] conducted a study to assess the awareness, knowledge, attitude, and practice of 434 undergraduate dental students from five different institutions in Nepal in relation to medical waste management. Their findings indicate that the majority of the students had a positive attitude towards the management of waste; however, over half of the students surveyed were unaware of the strategies laid down by the government on proper medical waste management.

Abdullahi and Tuna [44] also investigated students' knowledge and perceptions of waste management and their environment via a survey with secondary schools, universities, and colleges in Nigeria. The results discovered an unsatisfactory knowledge of environmental issues. Boiyo et al. [45] surveyed 320 students randomly selected to determine the relationship between attitudes and environmental contribution in the urban district of Nairobi. Their findings show that attitude and the level of environmental contribution do not influence each other. However, the study did discover a positive relationship between attitude and environmental behavior.

Ahmad et al. [46] conducted a study to establish the relationship between students' knowledge, attitude, communication, and perception of their environment using higherlevel institution students. Their findings show that students were knowledgeable about the environment and waste management. However, this knowledge did not translate to behavior and practice. One of the impediments to practice was attributed to the lack of waste sorting facilities, as a weak relationship was established between students' knowledge, attitude, and practice.

He et al. [47] conducted a study to verify environmental knowledge in two regions of different levels of socio-economic development in China. The data obtained from all the sampled students showed that all the students had low levels of environmental knowledge, but have a positive attitude to change. Students brought up in rural and non-rural settings had significantly different levels of environmental knowledge. The majority of the study reviewed presented a weak relationship between knowledge, attitude, and perception. 


\subsection{The Interconnection of Environmental Knowledge, Attitude, and Behavior}

Several studies have looked into the link between environmental knowledge and behavior. Environmental knowledge and environmental behavior should, in theory, have a positive relationship. As a result, the more informed a person is, the more concerned he or she will be about environmental issues. However, there is no definitive evidence of a link between the two.

One of the models used to describe the relationship between knowledge and behavior is the knowledge-attitude-behavior (KAB) model [48], and according to this model, environmental knowledge leads to the establishment of environmental attitudes, which later reflect in behavior. It has also been argued as necessary to improve behavior based on the notion that people who are environmentally aware are also aware of associated problems, and so have a greater reason to take constructive action in response to them [49]. This, on the other hand, has been criticized as being superficial because it ignores the interconnections of factors that impact behavior [50]. Although many studies have demonstrated that knowledge alone is not sufficient to impact behavior, it has been found in a number of studies to be a precondition for a person's behavior [51]. The justification for this stance is that environmental concerns are complicated and understanding and acting on them necessitates a basic understanding of their true nature [51]. Scientific data have demonstrated that a person's level of environmental knowledge influences their behavior toward the environment. In this case, a higher level of environmental knowledge is more likely to result in the development of environmental behavior [51,52]. According to other studies, more environmental knowledge does not necessarily influence environmental behavior $[53,54]$.

It is necessary to understand knowledge, attitudes, and perception (KAP) in order to make a meaningful transition toward sustainability. As a result, promoting education for sustainable development is critical. The 2030 UN Agenda's SDG 4.7 states that by 2030, all students must be equipped to "get the required knowledge and skills needed to promote sustainable development" [21]. Priority action three of the global action program (GAP) 2015-2019 [55] and the ESD beyond 2019 framework expresses the same aim, emphasizing that "developing capacity of educators and trainers" remained a priority [56]. This is also expressed in UNESCO's five pillars of education, which are: knowledge to know (pertaining to learning), knowledge to do and live cooperatively, and knowledge to become and to transform personally and societally [57]. It has been shown that well-educated youngsters may use their role as citizens and change-makers to initiate and promote sustainable development [57].

\subsection{Circular Economy Competencies and Sustainable Development Competencies for Sustainability in Higher Education}

Within education and learning for a sustainability community, a new discourse has emerged, arguing that students require some basic competencies to interact constructively and ethically with today's complex and unsustainable environment. "Competencies reflect the precise traits and human need for action and self-organization in diverse complicated settings" [58]. They are an interaction of knowledge, capacities and skills, motives, and affective dispositions, and they contain cognitive, affective, volitional, and motivational factors. They cannot be forcibly learnt; instead, they must be developed by the learners. They are learned through experience and reflection [58].

The eight key sustainability competencies are: "systems thinking competency, anticipatory competency, normative competency, strategic competency, collaboration competency, critical thinking competency, self-awareness competency, and integrated problem-solving competency" [59]. These eight key competencies are what citizens need to possess to be able to deal with today's complex challenges. They are considered relevant to all SDGs and enable individuals to relate the different SDGs to each other, i.e., to see "the big picture" of the UN 2030 Agenda for Sustainable Development [60]. 
Higher education, without a doubt, plays a critical role in the global transition to a circular economy. Across the globe, there is growing momentum in sectors to transition into the circular economy domain, from teaching and learning to research and student action. A circular economy (CE) is a viable alternative to the linear economy, based on the take-make-dispose concept. Proponents of this economic model believe it is a realistic means of achieving high levels of sustainability without compromising institutional profit or lowering the amount of products and services available. In other words, a circular economy aims to do more than just correct the flaws of a linear economy; it also entails a systemic shift that entirely transforms the economic structure [61].

Three key principles underpinning the CE concept are (1) waste and pollution reduction (this notion proposes minimizing economic damages to reduce waste and pollution); (2) product and material usable life extensions (to extend the usable life of products and resources by establishing loops of materials and products that circulate throughout the economy) - the goal is realized by the active reuse, repair, and remanufacturing of the economy's products and materials; (3) the regeneration of natural systems, which increases natural capital and generates the necessary circumstances for natural systems to regenerate [61].

Several higher education institutions from around the world have joined the Ellen MacArthur Foundation (EMF) to help establish academic curricula, research capabilities, and joint enterprises based on the $\mathrm{CE}$ concept. As a response, HEIs have begun to launch CE-focused research programs in response to the problems of mainstreaming CE [62]. To embed CE thinking across HEIs, however, a number of obstacles must be overcome, including a general lack of awareness and understanding of its meaning and benefits; conservative governance structures, operating models and mindsets; weak policies, regulations, partnership and frameworks, along with time and financial constraints. This is being done while also taking into account the unique obstacles that each country and institution faces [62].

\section{Methods}

\subsection{Overview of the Institution of Study}

The University of Venda (Univen), which lies in the northernmost part of South Africa, is an indigenous institution situated in Thohoyandou, Limpopo Province, South Africa. It is a multi-cultural university that attracts students and staff from various parts of Africa owing to its traditionally preserved heritage, rich bio-cultural diversity, and historical advantage. The university had 16,702 enrolled students and 490 members of staff in the 2019 academic year. The university comprises nine academic schools, eleven students' hostels, and one staff and student administrative building.

\subsection{Sampling Procedure}

A cross-sectional survey was conducted among the registered students of Univen in $2019(\mathrm{~N}=16,702)$. A total of 376 students were included in this survey. The sample size for the study was determined using Equation (1) [63].

$$
\text { Sample size }=\frac{Z^{2} \times(P) \times(1-P)}{C^{2}}
$$

where $Z=Z$ value (e.g., 1.96 for $95 \%$ confidence level), $P=$ percentage picking a choice, expressed as a decimal ( 0.5 used for sample size needed), $C=$ margin of error, expressed as a decimal (e.g., $0.05= \pm 5)$.

\subsection{Data Collection}

Data for this study were collected using a research tailored questionnaire. The questionnaire utilizes a mixture of open- and closed-ended questions to assess the perception, knowledge, and attitude of students regarding solid waste management at the University of Venda. The reliability of the questionnaire was confirmed by distributing it among 
30 students as a pre-test. The content validation method was utilized at the introductory stage as the data collection tool, during which each item in the questionnaire was compiled according to the aim of the investigation. The sampling frame consisted of 395 students. There were 376 returned completed questionnaires, equivalent to a $95 \%$ response rate. This sample represented a probabilistic sample, as it was selected through stratified random sampling.

The questionnaire is comprised of three sections. The first section contains the demographic statistics of the respondents (gender, age, student level of education, and school). The second section measures the student's perception and attitude towards waste management on the Univen Campus. The third section seeks the perceptions of students regarding recycling in the institution, possible solutions, and suggestions to improve waste management in the institution.

The knowledge, attitude, and perception of the students were rated based on their scores at three levels of low ( $<50 \%$ of the score), average ( $50-75 \%$ of score), and good ( $>75 \%$ of score). The respondents were undergraduates and postgraduates of the University of Venda: 1 st year-10\% $(n=39)$; 2 nd year- $15 \%(n=56)$; 3rd year $-20 \%(n=75)$; 4 th year-20\% $(n=75)$; postgraduates-20\% $(n=75)$. The respondents were $45 \%$ male and $55 \%$ female. Their age varies between $<21$ years $(\mathrm{n}=94,25 \%), 21-20$ years $(\mathrm{n}=207,55 \%)$ and $>30$ years $(n=75,20 \%)$.

The conceptual circular model was developed using the results of the KAP survey following the guideline of the RESOLVE framework established by [61] and the CE vision proposed by [64].

\subsection{Statistical Analysis}

The descriptive and analytical statistics of the data collected were assessed using SPSS software (version 25.0). The data were tested firstly for outliers and normality of distribution using skewness and kurtosis indices. The results show that the distributions of all the items did not deviate significantly from normality. The parameters calculated include percentages and frequency. The statistical analysis performed also included crosstabulations to test the relationship between the level of education and knowledge, attitude, and perception in the students. The visualization of data has been achieved with tables, pie charts, and histograms.

\subsection{Ethical Consideration}

Ethical clearance for this research was obtained from the University of Venda Research Ethics Committee (approval number SES/19/ERM/05/1206).

\section{Results and Discussion}

\subsection{Perception, Knowledge, and Attitudes of Students Regarding Solid Waste Management}

A very important aspect of environmental education is the dissemination of information on matters of environmental concern to the academic community as an entity, which includes students, staff, and other workers. The results from the questionnaires indicate that $88 \%$ of the students did not know those responsible for solid waste management in the institution. This high percentage of respondents not knowing the responsible personnel is an indication of the need for awareness. Students must have adequate knowledge of the personnel responsible for solid waste management in the institution. This could encourage effective communications of feedback and suggestion.

Keles [65] opined that higher institutions of learning have the responsibility to pioneer the process of building knowledge, and inculcating skills, awareness, values, and sustainable attitudes, in order to enable a sustainable environment. This makes the leaders of future generations innovative and critical reasoners, helping towards a sustainable environment. To assess the performance of the current waste management system in the institution, the students were asked to rate it from the range of excellent to bad (Table 1). 
Table 1. Rating of current waste management.

\begin{tabular}{ccc}
\hline & Frequency & Percent \\
\hline Excellent & 9 & 2.4 \\
Good & 213 & 56.6 \\
Inadequate & 154 & 41.0 \\
Total & 376 & 100.0 \\
\hline
\end{tabular}

The results show that $56 \%$ of the respondents rated the university's waste management as ideal, while $41 \%$ of the respondents regarded it as inadequate. In a comparative study by [66] at Accra University, 50\% of the students expressed that they were impressed with the current state of their school, while others reported problems with the sanitary conditions of the hostels and their environment.

\subsection{Perceived State of Environmental Cleanliness in the Institution}

Cleanliness of the environment is often depicted as an important measure of the effectiveness of solid waste management in the community. A few questions were asked on the state of cleanliness of the university campus. The responses received reveal that above $50 \%$ of the respondent were not satisfied with the current environmental state of the institution. This is because the good sanitation and cleanliness of an environment is a vital aspect of the health and general well-being of the users. Campbell et al. [67] reported a positive correlation between the environmental cleanliness and increased learning of students at Brigham Young University, United States. Similarly, Tagor et al. [68] showed a correlation between a healthy school environment and student's behavioral disposition. Their results also indicate that a clean and sanitary school environment is a major determinant of the attitudinal lifestyle and performance of the students in Indonesia. Table 2 shows the perceived areas of concern of the students.

Table 2. Areas of perceived concern.

\begin{tabular}{lcc}
\hline \multicolumn{1}{c}{ Unsatisfactory Areas } & Frequency & Percent \\
\hline Student's residences & 63 & 16.8 \\
Lecture halls & 6 & 1.6 \\
Cafeteria & 2 & 0.5 \\
Others & 5 & 1.3 \\
Student's residence and lecture rooms & 13 & 3.5 \\
Student's residence and cafeteria & 55 & 14.6 \\
Student's residence, lecture rooms and cafeteria & 66 & 17.6 \\
Total & 376 & 100.0 \\
\hline
\end{tabular}

From the results obtained, the residence, lecture rooms, and cafeteria are the places that the students identified they would prefer to be neat all the time (17.6\%). This shows that these major areas require the most attention, as students spend most of their productive time in these places for classes, reading, sleeping, and eating, and this could have an impact on their well-being and academic performance. This agrees with research conducted by [69], which reveals that students spend most of their time in these areas and thus they should be given the required attention.

\subsection{Littering on Campus}

Littering refers to the act of indiscriminately discarding or deliberately disposing of items that are no longer of use in an undesignated place, and in most cases, such items can be recycled. Students were asked if they perceive littering as an environmental problemthe majority of the respondents identified that littering is a problem in Univen (68.4\%), and the most commonly littered areas of the university are presented in Figure 2. This finding is congruent with the findings of [70], where students identified littering as a major 
environmental problem. This result also concurs with the study of Karkkainen et al. [71], wherein learners identified littering as a national and global problem.

\section{Most littered Areas}

student residence, lawn, cafeteria halls, lecture room, lawn

halls, lecture room, cafeteria

student hall and cafeteria

student hall and lawns

residence and lecture rooms
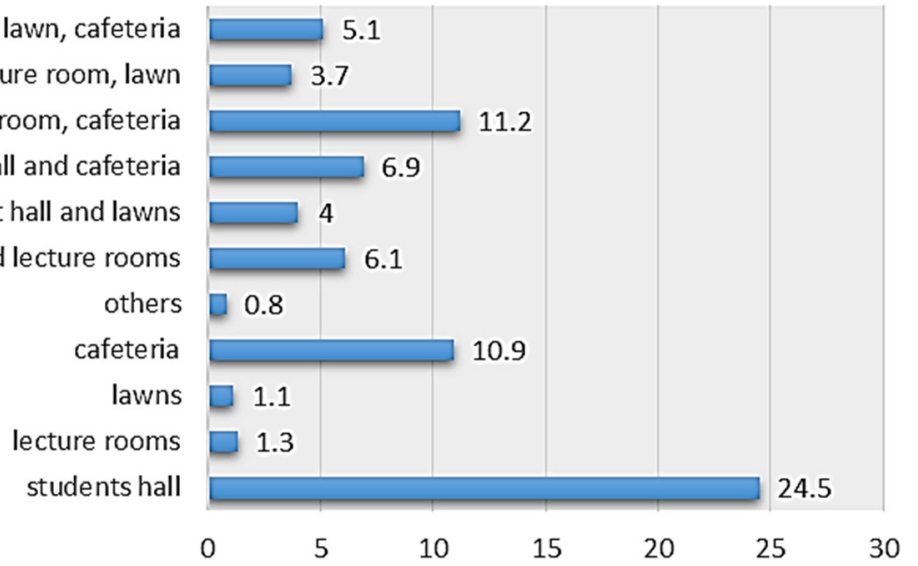

Figure 2. Most littered areas (source: Author's work).

Students reported that the hall of residences, lecture rooms, and cafeteria are the most littered areas on campus. Littering in the academic environment speaks about the level of environmental commitment of an institution, such that it encourages bad littering habits in students and projects a negative image of the institution, which must be curbed [72]. In a deliberate attempt to combat littering, the Green Campus Initiative (GCI) at the University of Cape Town began a waste management scheme with a two-container framework in 2012, which enabled students to isolate "recyclables" from "non-recyclables" [73]. Good hygienic practices should be encouraged in hotspots areas because they can lead to health problems for the students.

\subsection{Practices of Students Regarding Solid Waste Management}

\subsubsection{Attitudes to Waste Disposal Amongst Univen Students}

To determine the culture of waste disposal amongst students, they were asked where they dispose of their waste. The majority of them $(n=356,93.6 \%)$ claimed that they dispose of their waste adequately using the provided waste bins; some of the respondents, however, complained that the bins are not sufficient $(n=176,46.8 \%$ ) for effective solid waste management on campus. This is different from a similar study in Ghana by [74], where the majority of the respondents $(n=120,83.33 \%)$ indicated that waste is discarded in open spaces in senior high schools within the Wa Municipality, while $8.33 \%$ indicated that waste is disposed of in dustbins. This suggests that the provision of an adequate number of waste bins can influence the attitudes of students towards effective waste management.

The type of waste bins employed for use in tertiary institutions has been implicated to affect the attitude of students towards waste disposal [75]. Students reported their experiences in using the waste bins provided. Some of the students (44\%) reported that there are difficulties associated with the use of the provided bins (Figure 3). 


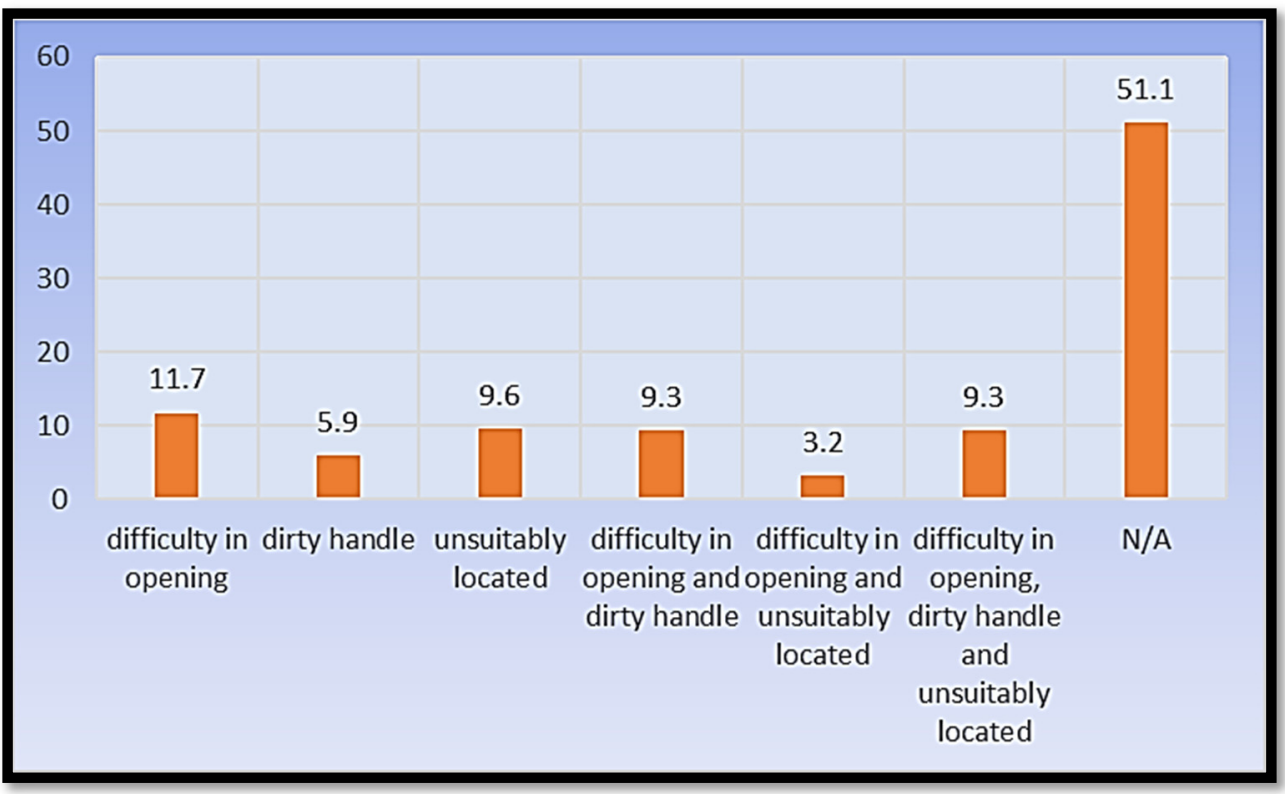

Figure 3. Difficulties with the waste bins (source: Author's work).

The most commonly reported difficulty is in the opening of the bin lid and dirty handles (11.7\% and 9.3\%). Physical inspections of some of the types of bins provided revealed a long heavy iron handle that is difficult to open (Figure 4), which is a demotivating factor for effective usage. However, some other kinds of bins without handles were also provided for solid waste management in the university. An interview with relevant personnel stated that some of the bins provided have heavy lids because of the threats of monkeys who scavenge the bins for food items, thereby producing litter on the premises. Cleaners can be encouraged to clean the lids of the bins daily to encourage their use. Alternatively, the institution can put sanitary materials around the bins, which students can use to clean the bin handle before use.

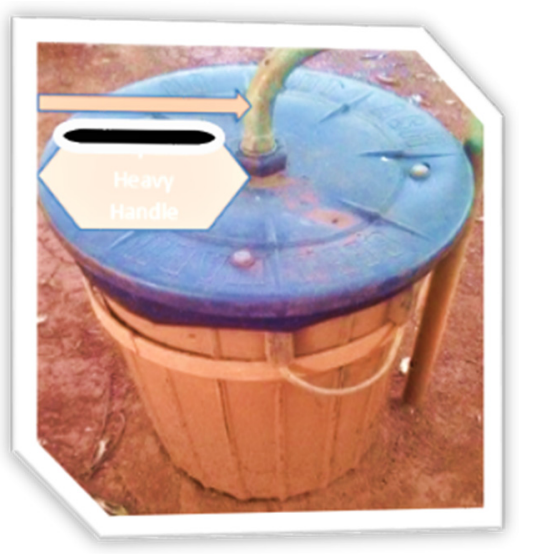

Figure 4. A sample of a typical bin with a long handle (source: Author's field work).

A study carried out by Katherine [76] concluded that to encourage and facilitate students in the efficient use of waste receptacles, waste bins must be unified and aesthetically pleasing to users. Similarly, Duffy and Verges [77] observed that some lid openings are capable of constituting barriers to effective usage and discouraging users from compliance. Through their study, it was shown that some types of lids can promote reductions in waste at a rate of $95 \%$, and it was therefore concluded that some designated lids can increase the proper utilization of waste bins. 


\subsubsection{Awareness of Waste Separation}

Waste separation is fundamental for any effective waste management process. Research on the driving mechanisms of waste separation by Feiyu et al. [78] showed that the extent to which the recycling and reduction process can be effectively carried out in any waste reduction scheme is largely dependent upon waste separation at the source.

The respondent's knowledge regarding waste management and separation was tested, and the majority of them (70.7\%) had no idea of what waste separation is all about; this raises the need for awareness on waste management. When those who claimed to have adequate knowledge about waste separation were further asked about its advantages, more than half $(60 \%)$ indicated that they did not know (Table 3). This response is similar to those received by Alam and Ahmade [79], whose study found that the knowledge and attitudes of students related to waste management were generally low. The cross-tabulation between students' level of study and their knowledge on waste separation is presented in Figure 5.

Table 3. Knowledge on waste separation.

\begin{tabular}{ccc}
\hline & Frequency & Percent \\
\hline Yes & 110 & 29.3 \\
No & 266 & 70.7 \\
Total & 376 & 100.0 \\
\hline
\end{tabular}

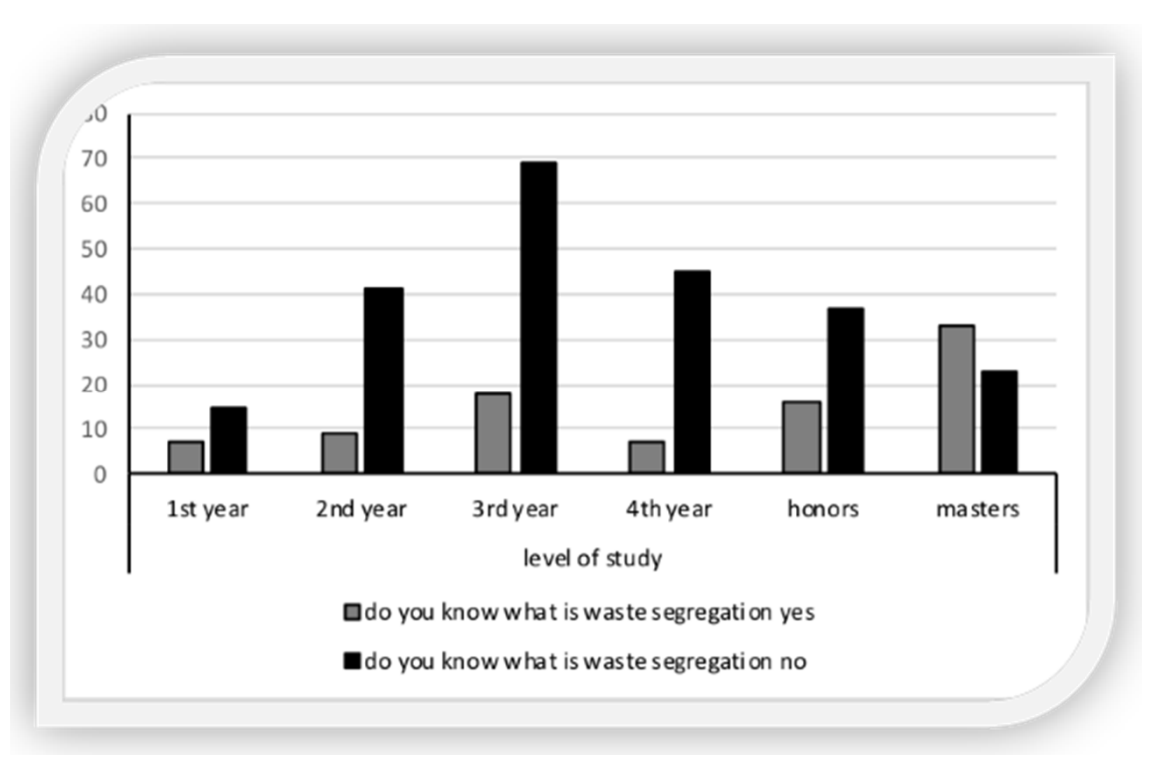

Figure 5. Cross-tabulation of the level of study and knowledge of waste segregation (source: Author's work).

The cross-tabulation shows that a higher percentage of students across all levels of study do not know what waste segregation is compared to those who do; furthermore, there is an exception at the master's level of study, where a larger percentage of students reported to know what waste segregation is about. The reason for this low knowledge could be a lack of environmental education in the institution. With the foregoing, it is evident that there is a need for thorough and deliberate waste management education in the institution.

To establish whether waste separation is being practiced in the institution, students were asked if there are different waste bins for different types of waste generated. It was revealed that such practice does not exist $(77 \%)$ in the university. The percentage of respondents $(22.9 \%)$ who indicated that waste separation is being practiced in the institution was unexpected, because there is no form of waste segregation at the university. The reason for this $(22.9 \%)$ could be their lack of understanding of the subject of waste separation. 
This is similar to findings reported by Ampofo [74] derived from senior school students in Ghana, where all the respondents $(n=120)$ indicated that they do not separate plastic waste, glass waste, and organic waste in their schools because it is not being practiced in the institution. Waste separation at the source improves the process of sustainable waste management, and decreases the amount and cost of disposal.

The lack of waste separation bins causes a significant hindrance to waste diversion and recovery opportunities, such as recycling with its many advantages. Students were asked the reasons for the non-separation of their waste, and the responses are presented in Figure 6. It can be deduced that the highest percentage of reasons for why waste is not segregated in the institution is lack of awareness (44.1\%) and lack of separate recycling bins $(30.3 \%)$. Important lessons can be learned on waste management from developed countries, for instance the United States of America, where all institutions are mandated to provide separate waste bins for waste separation. Therefore, for a meaningful waste management scheme to kick off, it is suggested that waste management education be intensified, possibly as part of curricula with practical actions, such as the provision of appropriate waste recycling bins. It was also pointed out by Limon and Vilarino [80] that the lack of garbage facilities discouraged people from practicing proper waste reduction.

\section{Reasons for non-segregation of waste}

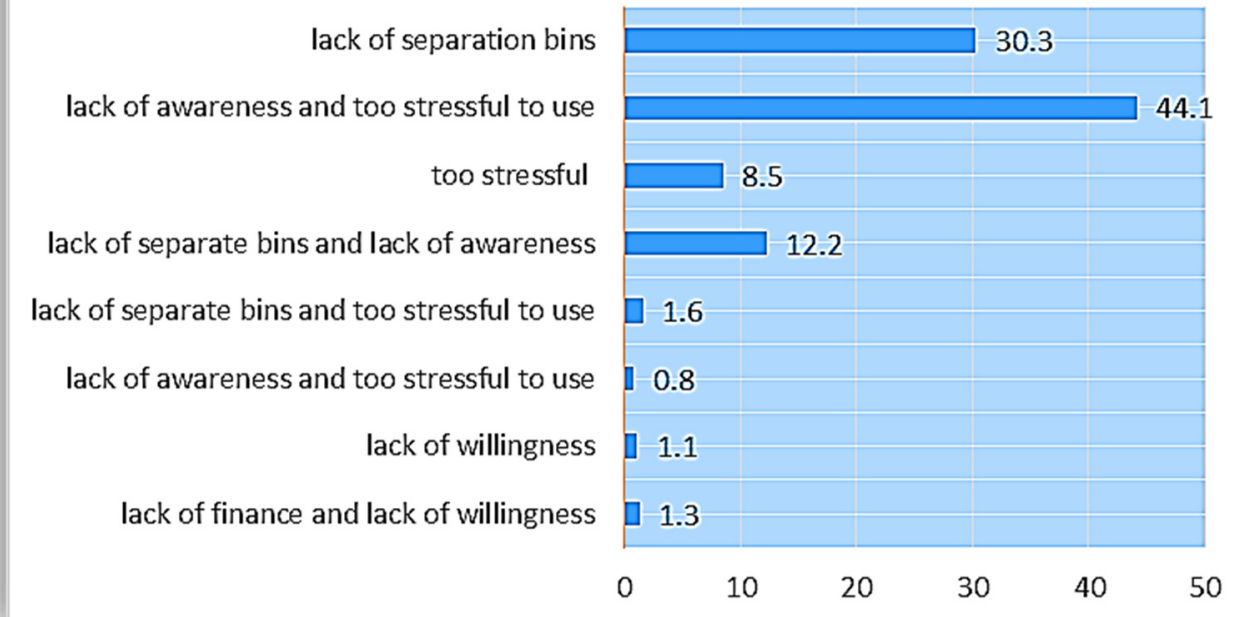

Figure 6. Reasons for non-segregation of waste (Source: Authors work).

\subsubsection{Respondents' Perception and Attitude towards Recycling}

As argued by Velaquez et al. [6], recycling does not only improve campus sustainability or income generation, but also contributes to the sustainability of the immediate community and country by cutting down excessive resources consumption and lowering the negative impacts on the environment. However, several factors contribute to successful recycling, and the most important is the motivation to recycle, as well as the fulfillment associated with it. We sought to determine the mindsets of students towards recycling, and what will be their attitude if there are provisions for recycling waste bins. The responses are given in Table 4.

From Table 4, we see that the majority of students (77.9\%) agreed that waste separation adds value to resources, even though they may not have experienced it or know how it works. Upendra et al. [81] observed that in Sweden, over half of the respondents (74.16\%) attached value to waste segregation. Similarly, Philippsen [82] also reported that over half $(71.1 \%)$ of the students at the University of Twente indicated that waste separation is highly important. 
Table 4. Students' perceptions of recycling.

\begin{tabular}{ccc}
\hline \multicolumn{3}{c}{ Segregation of Waste Adds Value to Waste Resources } \\
\hline & Frequency & Percent \\
Agree & 293 & 77.9 \\
Undecided & 60 & 16.0 \\
Disagree & 23 & 6.1 \\
Total & 376 & 100.0 \\
\hline
\end{tabular}

Table 5 also shows that $81.4 \%$ confirmed that if provided with the necessary materials, they would be willing to recycle their waste. This is an expression of willingness to recycle if the institution provides the necessary materials and support. Emmanuel and Adams [83] in their study among college campuses in Alabama and Hawaii indicated that students were concerned about their environment and the conservation of resources, and as such were willing to take part in such sustainable practices. Additionally, students at the North American University expressed their willingness to separate waste and recycle, provided the facilities were available, and this was established through a study on the student's recycling attitude by [84]. Therefore, the efficient provision of service is critical to a successful recycling scheme.

Table 5. Students' willingness to separate waste.

\begin{tabular}{ccc}
\hline \multicolumn{2}{c}{ If Necessary, Materials Provided, I Will Separate My Waste } \\
\hline Opinion & Frequency & Percent \\
Agree & 306 & 81.4 \\
Undecided & 49 & 13.0 \\
Disagree & 21 & 5.6 \\
Total & 376 & 100.0 \\
\hline
\end{tabular}

From Table 6 , we see that $41 \%$ of the respondents believe there should be an incentive to enable them to separate their waste. Several studies have shown that to attain a sustainable waste management system, one option is to implement what are called "recycle drivers", such as economic incentives that positively influence the recycler's decision and attitude towards recycling. Abila and Kantola [85] conducted a study on the role of incentives in promoting waste recycling in Finland, and the results from their study show there is a direct relationship between waste management and financial incentives.

Table 6. Financial incentives to separate my waste.

\begin{tabular}{ccc}
\hline \multicolumn{2}{c}{ I Believe There Must Be Financial Incentives to Separate My Waste } \\
\hline & Frequency & Percent \\
Agree & 154 & 41.0 \\
Undecided & 114 & 30.3 \\
Disagree & 108 & 28.7 \\
Total & 376 & 100 \\
\hline
\end{tabular}

Thorgesen [86] explored the effect of financial motivation on waste separation and recycling using two controlled groups, wherein one group were payed a fixed rate for waste collection and the other were payed according to the weight of the waste. The results show that the group that were payed according to the weight of the waste recycled more. Tam and Tam [87] adopted a stepwise incentive scheme (SIS) to reduce waste generation in Hong Kong, and the study proved that SIS could help reduce wastage generation by up to $23.60 \%$. In a study by Alessandro et al. [88], it was established that the "pay as you throw" (PAYT) incentive scheme increases the willingness of respondents to recycle by over $12 \%$, thereby supporting financial incentive as a strong tool to improve recycling 
attitude and waste management. There are environmental and economic benefits to be derived from recycling, and when people are aware of this, it makes it easier to engage in recycling activities. We posed an awareness question to ascertain if the students know the benefits associated with recycling. More than $40 \%$ of the respondents did not know the importance of recycling (Table 7), which is an indication of the need for consecutive awareness programs on environmental cleanliness. Furthermore, when the respondents were asked if they knew of any environmental club within the institution, the majority responded they did not know (96\%). This is surprising, as there is an environmental club named Universal Greening Organization (UGO) at the university. The club and the university management should take up the challenge to sensitize the students and staff on the importance of recycling.

Table 7. Environmental benefits of recycling.

\begin{tabular}{ccc}
\hline \multicolumn{3}{c}{ Knowledge of Environmental Benefits of Recycling } \\
\hline \\
Yes & Frequency & Percent \\
No & 212 & 56.4 \\
Total & 164 & 43.6 \\
\end{tabular}

\subsection{Potential for Recycling}

We asked whether the solid waste generated in the institution has recycling potential, and students indicated that there is potential for recycling $(88.3 \%)$ the waste generated by the institution. This is an indication that there is the opportunity for waste reduction and diversion through recycling in the institution, which should be adequately harnessed. For example, in a study at the University of Venda, the waste profile revealed that $61.7 \%$ of waste generated is recyclable, and $34.4 \%$ is classified as compostable [89]. The majority of the students $(64.9 \%)$ believe the current waste management system of the university needs to be improved. The suggestions made by the respondents are presented in Table 8 . The next section presents a summary of the most relevant findings from the KAP survey used to conceptualize a circular economy and identify future areas for improvement as shown in Figure 7.

Table 8. Summary of KAP results and suggestions to improve circularity.

\begin{tabular}{l} 
Major Identified Barriers \\
\hline 1. Students' lack of awareness of CE \\
2. Students' lack of knowledge on CE practicability \\
3. Limited budget and financial constraint \\
4. Lack of tools (standard waste separation bins) \\
$\qquad$ Major Identified Motivators \\
\hline Key Instruments for Circularity \\
1. Financial incentives \\
2. Provision of essential tools and materials \\
1. The establishment of education and awareness programs on environmental and waste \\
management, this can be in form of orientation or part of their academic curriculum. This will \\
address the challenge of ignorance and motivate towards sustainable management of waste. \\
2. The provision of modern recycling labeled waste bins to separate waste from source. \\
3. Provision of more sufficient and user-friendly bins that are easier to open. \\
4. The need to employ more waste management teams. \\
5. Strict monitoring process of waste bins provided, and sanction for any caught erring. \\
6. Timely collection of waste from residences and within the campus. \\
\hline
\end{tabular}




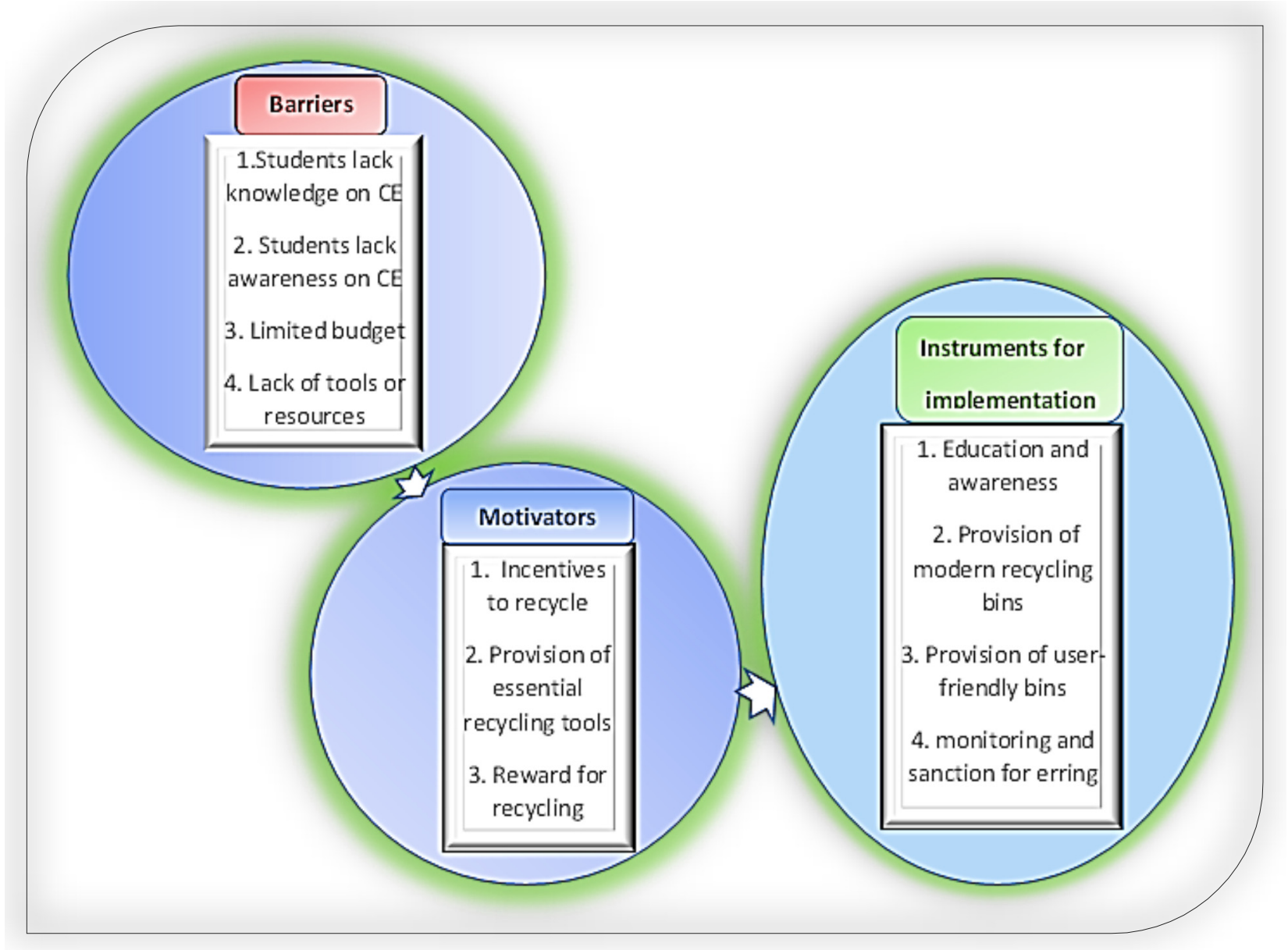

Figure 7. Circular structure to improve waste management at the university (source: Authors work).

\subsection{Towards Conceptualizing a Circular Economy for the University}

The KAP survey in this study represents an introductory step to building a circular economy vision that would enable the institution to take basic progressive strides towards achieving circularity. Although these marginal changes do not themselves constitute the ultimate required shift from linearity to a circularity philosophy, they do characterize the needed steps, targeted at empowering the stakeholders (students and the staff). The analogy of the KAP survey with circular economic principles is analyzed using the "ReSOLVE" checklist developed by the Ellen McArthur Foundation [61].

The ReSOLVE framework incorporates the following six action areas for institutions and organizations to move towards a circular economy: regenerate, share, optimize, loop, virtualize, and exchange. As proposed by Mendoza et al. [64], institutions and organizations should examine and discuss this framework by first identifying some foundational requirements that can sustain the implementation of $\mathrm{CE}$. The critical foundational requirement is the building of vision, which requires identifying the barriers and motivators needed to achieve the CE principles.

This is also coherent with the institution's principal goals and priorities, which are key to fully realize the prospect of attaining circularity. The building of the CE vision is helpful to redefining the path and scope of the institution's prospective activities and direct decision-making procedures in order to build effective circularity and sustainable institutional schemes. Thus, this study, carried out via a KAP survey, has identified barriers to and motivators of CE implementation in the institution, as a foundational requirement of circular economy implementation and building a circular economy vision in a rural university such as the University of Venda, from the point of view of the students a major stakeholder in the institution. 
This will support them in taking the necessary measures to make CE implementation successful. From the previous section, it can be seen that four critical factors pose a challenge to implementing CE in the institution, which include lack of knowledge, and students' lack of awareness. Additionally, motivators such as incentives and financing for the tools required for resource recycling are vital for the transition at this stage. To develop a CE conceptual model, these variables are grouped under three categories, namely, identified barriers, identified motivators, and key instruments for circularity. The resultant conceptual model for the application of CE in the institution is given in Table 8.

\subsection{Limitation and Directions for Future Research}

This study is not without limitation. As regards the KAP analysis, the data on the practices of the students regarding waste management were collected quantitatively via a questionnaire. We posit that a blend of questionnaires and interviews would capture a broader view.

Future research could explore lessons derived from students' participation in projects on environmental waste management using a mixed method, as this can be useful in empowering and sensitizing others to follow. Additionally, the use of social media communication in developing environmental knowledge, transitioning to circularity, raising awareness about specific environmental issues, and informing students about the positive effects of recycling behavior can be explored. This is because students are more inclined to use social media, and this has an influence on their actions and behavior.

Moreover, considering that this is the era of industry 4.0, future research could be directed towards understanding the opportunities of gamification for waste circularity and environmental education, so as to inspire a more positive relationship between students and their environment. Gamified waste management offers a unique means for institutions to increase their pro-environmental behavior and recycling practices. Recent studies have proven that gamification can be a valuable tool to promote sustainable behavior in different environments [90].

\section{Conclusions}

This article aimed to investigate knowledge, attitude and perception (KAP) related to solid waste management from the perspectives of students at a rural-based university. It also sought to determine their current practices regarding solid waste management and identify steps that can be taken towards a circular economy vision in the institution. From this perspective, the KAP analysis was fundamental, and enabled a methodical exploration to reveal the motivators of and barriers to circularity in the institution. The study made the following findings: The level of knowledge and awareness of solid waste management is low. The current practices of the students in terms of waste management are not in line with the CE framework. The study highlighted barriers such as a lack of knowledge, awareness and proper facilities, and financial constraints, as major challenges to $\mathrm{CE}$ implementation. In three ways, our work has enriched the policy discussion on rural youth in higher education and sustainability: To begin with, it is the first attempt to determine the students' level of knowledge on solid waste management in a rural setting. Second, it assesses the barriers and constraints to rural institutions' achievement of the CE goal. Finally, it proposes an institution-wide CE framework.

Drawing on the literature on "Education for Sustainable Development", this study identifies the need to strengthen three of the eight key sustainability skills highlighted in the literature, as these three competencies are particularly relevant to the context of this study. Firstly, as previously said, based on the results of the study, there is lack of knowledge and awareness, which necessitates the promotion of "self-awareness competency" among the students. This will increase learners' ability to reflect on their personal role in the local community and (global) society, continuously review and further motivate their personal actions, and deal with personal sentiments and wants as a result of this. Secondly, given the institution's goal of transitioning to a more circular economy, the current practices of 
the students in waste management are not in line with the CE framework, as indicated by the lack of suitable waste segregation facilities, as presented in the results. This further suggests the need to develop "integrated problem-solving competency", which gives learners the broad ability to apply various problem-solving frameworks to difficult sustainability problems and come up with credible, inclusive, and fair solutions that support sustainable development. This competency is developed in this research through the integration of the resolve framework, discussed in Section 4.5. Thirdly, the study focuses on rural youth in higher education and sustainability, and has identified a lack of systems thinking among this set of students due to their lack of information and exposure. This brings forward and emphasizes the need to promote "systems thinking competencies" in the institution. This is critical to informing students in rural institutions that they are part of a system that interacts with other parts (students from non-rural institutions) to ultimately function as a whole in order to achieve the 2030 Agenda's SDGs (goal 4), which aim to ensure inclusive and equitable-quality education and promote lifelong learning opportunities for all.

\section{Research Implications}

In practice, the findings of the study highlight the need for rural-based institutions to invest in sustainable strategies to meet the SDGs, as well as to increase students' awareness of sustainable waste management, which will benefit society, the environment, and the institution. Socially, the research contributes by encouraging discussions on sustainability in rural institutions, which is an important problem for society today in relation to fostering inclusivity and addressing the rural-urban divide in the transition to sustainability. Furthermore, it can aid in the dissemination of sustainability competencies in educational institutions, in an effort to reduce negative effects on the environment. Implementing the circularity framework in the institution will incorporate learners in societal transformations, and also support the development of learning and other behaviors that improve one's competencies in accordance with the five pillars of education outlined by UNESCO, which are knowledge to know (pertaining to learning) knowledge to do and live cooperatively, and knowledge to become and to transform personally and societally.

The study concludes that the existing solid waste management approach of the university should be improved to cater for recycling. There is a need for integration and partnership with the students as both youths and major stakeholders in a sustainable waste system, and the starting point is an understanding of the perceptions of the students regarding solid waste and littering in the institution.

Environmental education aimed at reducing waste generation and transitioning to $\mathrm{CE}$ is recommended. The article has conceptualized a CE vision as the first step towards a circular economy in the institution. The authors conclude that there is great potential for adopting a circular economy model in the institution in the long run, which extends to building capital from waste and thus harnessing and empowering the students in the pursuit of sustainable development.

Because the findings are based on a South African rural institution, any generalizations must take into account the reality that institutional sustainability challenges may differ from one place to another. As a result, place-specific guidelines must be developed, with the ability to understand the unique context of the local environment. The same frame can be replicated in similar rural institutions in the global south or similar communities anywhere in the world by using the above key instruments for circularity, or by modifying them in accordance with the area's developmental needs.

Author Contributions: Conceptualization, O.M.O. and J.N.E.; methodology, O.M.O., J.N.E. and R.M.; original draft, O.M.O.; review and editing, J.N.E.; visualization, R.M.; supervision, J.N.E., R.M.; investigation and validation, J.N.E. All authors have read and agreed to the published version of the manuscript.

Funding: This research was funded by the University of Venda, grant number "G565". 
Institutional Review Board Statement: This research was reviewed by the University of Venda research committee. The ethical clearance was approved by the University of Venda Research Ethics Committee (approval number SES/19/ERM/05/1206).

Informed Consent Statement: Informed consent was obtained from all subjects involved in this study.

Acknowledgments: The author would like to thank (i) the Department of Ecology and Resource Management, students and staff of the University of Venda, School of Environmental Sciences, the facility managers and sanitation workers, and the university management for providing logistical support during the data collection in 2019; (ii) the anonymous referees who supplied useful comments on this paper.

Conflicts of Interest: The authors declare there is no conflict of interest.

\section{References}

1. Integrated Youth Development Strategy (IYDS) of South Africa 2012-2016 (Draft). National Youth Development Agency (NYDA), Johannesburg, South Africa. Available online: https://www.youthpolicy.org/national/South_Africa_2012_Draft_ Youth_Development_Strategy.pdf (accessed on 2 February 2019).

2. Alshuwaikhat, A.I. An integrated approach to achieving campus sustainability: Assessment of the current campus environmental management practices. J. Clean. Prod. 2008, 16, 1777-1785. [CrossRef]

3. Guo, B.; Liu, Y. Towards integrated municipal solid waste management: A case of Urumqi China. Adv. Mat. Res. 2014, 878, 3-14. [CrossRef]

4. Bradley, C.J.; Waliczek, T.M.; Zajicek, J.M. Relationship between environmental knowledge and environmental attitude of high school students. J. Environ. Educ. 1999, 30, 17-21. [CrossRef]

5. Ahmed, H.A.; Mohammed, S.S.; Mekhlafi, A. Attitudes of Sultan Qaboos University students towards some environmental problems and their willingness to take action to reduce them. J. Soc. Sci. 2008, 5, 9-15.

6. Velazquez, L.; Mingxia, N.; Sanchez, M. Deterring sustainability in higher education institutions. Int. J. Sustain. High. 2005, 6, 383-391. [CrossRef]

7. Boca, D.G.; Sarach, S. Environmental education and student's perception, for sustainability. Sustainability 2019, 11, 1553. [CrossRef]

8. Vega, C.; Ojeda-Benitez, S.; Barreto, M.E. Solid waste characterization and recycling potential for a university campus. Waste Manag. 2008, 28, 21. [CrossRef]

9. Zhang, N.; Williams, I.D.; Kemp, S.; Smith, N.F. Greening academia: Developing sustainable waste management at Higher Education Institutions. Waste Manag. 2011, 31, 1606-1616. [CrossRef]

10. Stats SA. Department of Statistics South Africa. 2019. Available online: http://www.statssa.gov.za/?p=12362 (accessed on 9 January 2020).

11. DEA. National Strategy for Sustainable Development and Action Plan (NSSD 1) 2011-Pretoria: Department of Environmental Affairs, Republic of South Africa. 2011. Available online: https://www.dffe.gov.za/sites/default/files/docs/ sustainabledevelopment_actionplan_strategy.pdf (accessed on 2 January 2022).

12. Spira, F. Driving the Energy Transition at Maastricht University Analyzing the Transformative Potential on Energy Efficiency of the Student-Driven and Staff Supported Maastricht University Green Office, University College. 2008. Available online: https:/ /link.springer.com/content/pdf/10.1007\%2F978-3-319-08837-2.pdf (accessed on 15 January 2020).

13. Levin, B. Putting students at the center of education reform. J. Educ. Change 2000, 1, 155-172. [CrossRef]

14. Liao, C.; Li, H. Environmental education, knowledge, and high school students' Intention toward Separation of Solid Waste on Campus. Int. J. Environ. Res. Public Health 2019, 16, 1659. [CrossRef]

15. Han, Z.; Liu, Y.; Zhong, M.; Shi, G.; Li, Q.; Zeng, D.; Zhang, Y.; Fei, Y.; Xie, Y. Influencing factors of domestic waste characteristics in rural areas of developing countries. Waste Manag. 2018, 72, 45-54. [CrossRef] [PubMed]

16. Kaplowitz, M.D.; Yeboah, F.K.; Thorp, L.; Wilson, A.M. Garnering input for recycling communication strategies at a Big Ten University. Resour. Conserv. Recycl. 2009, 47, 42-55. [CrossRef]

17. Pérez, A.V.; Gámez, M.R.; Briones, V.F.V.; Viteri, C.G.V.; Molina, L.A.V. Sustainable development seen from environmental training in university linkage. Int. J. Life Sci. 2018, 2, 12-20. [CrossRef]

18. UNEP; UNESCO. The Belgrade Charter. 1976. Available online: https://naaee.org/sites/default/files/153391eb.pdf (accessed on 2 January 2022).

19. UNESCO. United Nations Decade of Education for Sustainable Development (2005-2014) Framework for the International Implementation Scheme. 2005. Available online: http://unesdoc.unesco.org/images/0013/001311/131163e.pdf (accessed on 2 January 2022).

20. WCED. Our Common Future; Oxford University Press: Oxford, UK, 1987.

21. UNESCO. Education for Sustainable Development Goals. 2017. Available online: https://www.sdg4education2030.org/ education-sustainable-development-goals-learning-objectives-Unesco-2017 (accessed on 2 January 2022).

22. Scoones, I.; Stirling, A.; Abrol, D.; Atela, J.; Charli-Joseph, L.; Eakin, H.; Ely, A.; Olsson, P.; Pereira, L.; Priya, R.; et al. Transformations to Sustainability; Steps Working Paper 104; Steps Centre: Sussex, UK, 2018; pp. 618-622. 
23. UNFCCC. Adoption of the Paris Agreement; UN: New York, NY, USA, 2015.

24. IIASA. Transformations to Achieve the Sustainable Development Goals; IIASA: Laxenburg, Austria, 2018; pp. 1-157.

25. Cortese, A.D. The critical role of higher education in creating a sustainable future need for a new human perspective envisioning a sustainable future. Plan. High. Educ. 2003, 31, 15-22.

26. McKeown, R.; Hopkins, C. EE $\neq$ ESD: Diffusing the worry. Environ. Educ. Res. 2003, 9, 117-128. [CrossRef]

27. United Nations Educational, Scientific and Cultural Organization. Bonn Declaration. In UNESCO World Conference on Education for Sustainable Development; UNESCO: Bonn, Germany, 2009; pp. 1-6.

28. United Nations Educational, Scientific and Cultural Organization. Education for a Sustainable Future: A Transdisciplinary Vision for Concerted Action 1997. Available online: http://www.unesco.org/education/tlsf/mods/theme_a/popups/mod01t05s01. html (accessed on 2 January 2022).

29. Knapp, D. The Thessaloniki Declaration: A wake-up call for environmental education? J. Environ. Educ. 2000, 31, 3. [CrossRef]

30. United Nations Educational, Scientific and Cultural Organization. Global Education Monitoring Report-Place: Inclusive and Sustainable Cities; UNESCO: Paris, France, 2016.

31. United Nations Educational, Scientific and Cultural Organization. Shaping the Future We Want: UN Decade of Education for Sustainable Development (2005-2014) Final Report; UNESCO: Paris, France, 2014.

32. UCLG. Towards the Localization of the SDGs. Available online: https://www.uclg.org/sites/default/files/towards_the_ localization_of_the_sdgs.pdf (accessed on 31 December 2021).

33. Blanco-Portela, N.; Benayas, J.; Pertierra, L.R.; Lozano, R. Towards the integration of sustainability in Higher Education Institutions: A review of drivers of and barriers to organisational change and their comparison against those found of companies. J. Clean. Prod. 2017, 166, 563-578. [CrossRef]

34. Cleland, J.A. Critique of KAP studies and some suggestions for their improvement. Stud. Fam. Plan. 1973, 4, 42-47. [CrossRef]

35. Launiala, A. How much can a KAP survey tell us about people's knowledge, attitudes, and practices? Some observations from medical anthropology research on malaria in pregnancy in Malawi. Anthropol. Matters J. 2009, 11, 1-13. [CrossRef]

36. Vandamme, E. Concepts and Challenges in the Use of Knowledge-Attitude-Practice Surveys: Literature Review; Department of Animal Health, Institute of Tropical Medicine: Antwerp, Belgium, 2009.

37. Hoque, M.; Alam, M. What Determines the Purchase Intention of Liquid Milk during a Food Security Crisis? The Role of Perceived Trust, Knowledge, and Risk. Sustainability 2018, 10, 3722. [CrossRef]

38. Gonul Kochan, C.; Pourreza, S.; Tran, H.; Prybutok, V.R. Determinants and logistics of e-waste recycling. Int. J. Logist. Manag. 2016, 27, 52-70. [CrossRef]

39. Avery, E.; Park, S. Perceived Knowledge as Protective Power: Parents' Protective Efficacy, Information-Seeking, and Scrutiny during COVID-19. Health Commun. 2020, 36, 81-88. [CrossRef] [PubMed]

40. IIDS. Knowledge, Attitude and Practice (KAP) Survey under the Community-Based Alternative Schooling Project (CASP) in Kathmandu District. Kathmandu, Nepal Institute for Integrated Development Studies (IIDS). 2006. Available online: https:/ / www.jica.go.jp/project/nepal/0602442/02/pdf/Baseline_KAP_Surveyin_Kathmandu_2006_May.pdf (accessed on 31 December 2021).

41. GIZ. Knowledge-attitudes-practices on environmental awareness: From interviews and discussions in Vientiane, Khammouane, Houaphanh and Sayaboury Deutsche Gesellschaft Fur Internationale Zusammenarbeit (GIZ) GmbH, 2013. Available online: https:/ / www.giz.de/en/downloads/giz2013-en-kap-survey-laos.pdf (accessed on 31 December 2021).

42. Sibiya, J.E.; Gumbo, J.R. Knowledge, attitude and practices (KAP) survey on water, sanitation and hygiene in selected schools in Vhembe district, Limpopo, South Africa. Int. J. Environ. Res. 2013, 10, 2282-2295. [CrossRef] [PubMed]

43. Singh, T.; Ghimire, T.R.; Agrawal, S.K. Awareness of Biomedical Waste Management in Dental Students in Different Dental Colleges in Nepal. Biomed Res. Int. 2018, 2018, 1742326. [CrossRef]

44. Abdullahi, I.K.; Tuna, F. Nigerian Students' Knowledge and Perceptions About Environmental Problems and Management: A Case Study. Int. J. Sci. Knowl. 2014, 4, 26-34.

45. Boiyo, V.; Koech, P.M.; Manguriu, D. Environmental Attitudes and Ecological Behaviour among Students: A Case Study of Kibera and Kasarani Division in Nairobi, Kenya. Int. J. Interdiscip. Res. Innov. 2015, 3, 50-59.

46. Ahmad, J.; Noor, S.M.; Ismail, N. Investigating students' environmental knowledge, attitude, practice and communication. Asian Soc. Sci. 2015, 11, 284-293. [CrossRef]

47. He, X.; Hong, T.; Liu, L.; Tiefenbacher, J. A comparative study of environmental knowledge, attitudes and behaviors among university students in China. Int. Res. Geogr. Environ. 2011, 20, 91-104. [CrossRef]

48. Henley, N.; Donovan, R. (Eds.) Models of attitude and behaviour change. In Principles and Practice of Social Marketing: An International Perspective; Cambridge University Press: Cambridge, UK, 2010; pp. 125-157. [CrossRef]

49. Diaz-Siefer, P.; Neaman, A.; Salgado, E.; Celis-Diez, J.L.; Otto, S. Human-environment system knowledge: A correlate of pro-environmental behavior. Sustainability 2015, 7, 15510-15526. [CrossRef]

50. Robelia, B.; Murphy, T. Why do people know about key environmental issues? A review of environmental knowledge surveys. Environ. Educ. Res. 2011, 18, 299-321. [CrossRef]

51. Vicente-Molina, M.A.; Fernández-Sainz, A.; Izagirre-Olaizola, J. Does gender make a difference in pro-environmental behavior? The case of the Basque Country university students. J. Clean. Prod. 2018, 176, 89-98. [CrossRef] 
52. Navimipour, N.J.; Navin, A.H.; Rahmani, A.M.; Hosseinzadeh, M. Behavioral modeling and automated verification of a Cloud-based framework to share the knowledge and skills of human resources. Comput. Ind. 2015, 68, 65-77. [CrossRef]

53. Paço, A.; Lavrador, T. Environmental knowledge and attitudes and behaviours towards energy consumption. J. Environ. Manage. 2017, 197, 384-392. [CrossRef] [PubMed]

54. Barber, N.; Taylor, C.; Strick, S. Wine consumers' environmental knowledge and attitudes: Influence on willingness to purchase. Int. J. Wine Res. 2009, 1, 59-72. [CrossRef]

55. UNESCO. Roadmap for Implementing the Global Action Programme on Education for Sustainable Development; UNESCO: Paris, France, 2014.

56. UNESCO. Education for Sustainable Development beyond 2019: Paris; UNESCO: Paris, France, 2019; Available online: https: / / en.unesco.org/themes/education-sustainable-development (accessed on 1 January 2022).

57. UNESCO; UNEP. Youth Exchange: Climate Change and Lifestyles Guidebook; United Nations Educational, Scientific and Cultural ORganization (UNESCO): Paris, France; United Nations Environment Programme (UNEP): Nairobi, Kenya, 2011.

58. UN. Transforming Our World: The 2030 Agenda for Sustainable Development; UN: New York, NY, USA, 2015.

59. UNESCO. Global Education Monitoring Report 2015. Available online: https://en.unesco.org/sites/default/files/gap_pn1__esd_and_the_sdgs_policy_brief_6_page_version.pdf (accessed on 3 January 2022).

60. Dlouha, J.; Heras, R.; Mula, I.; Salgado, F.; Laura, H. Competences to Address SDGs in Higher Education. A Reflection on the Equilibrium between Systemic and Personal Approaches to Achieve Transformative Action. Sustainability 2019, $11,3664$. [CrossRef]

61. EMF. Delivering the Circular Economy: A Tool Kit for Policy Makers; Ellen MACArthur Foundation, (EMF): Cowes, UK, 2015.

62. Ghisellini, P.; Cialani, C.; Ulgiati, S. A review on circular economy: The expected transition to a balanced interplay of environmental and economic systems. J. Clean. Prod. 2016, 114, 11-32. [CrossRef]

63. Glenn, D. Determining Sample Size: Institute of Food and Agricultural Education, University of Florida. 2003. Available online: http:/ / edis.ifas.ufl.edu (accessed on 12 February 2019).

64. Mendoza, J.M.F.; Sharmina, M.; Gallego-Schmid, A.; Heyes, G.; Azapagic, A. Integrating backcasting and eco-design for the circular economy: The BECE framework. J. Ind. Ecol. 2017, 21, 526-544. [CrossRef]

65. Keles, O. Investigation of pre-service Science Teachers' Attitudes towards Sustainable Environmental Education. High. Educ. Stud. 2017, 7, 171-180. [CrossRef]

66. Adelaide, G.; Goddey, P. Sanitation in Accra Technical University Hostel and Its Environs: A Case Study of Accra Technical University Old Hostel. Int. J. Hosp. Manag. 2017, 1, 11-22.

67. Campbell, J.L.; Bigger, A.S. Cleanliness \& Learning in Higher Education. Facil. Manag. 2008, 24, 8-36.

68. Tagor, A.; Asep, S.; Etty, R.; Bambang, I. The relationship between clean school environment and student's clean life-style behavior in Indonesia Junior and Senior high school. Int. J. Sci. Technol. Res. 2018, 7, 100-104.

69. Kiplagat, H.; Khamasi, J.; Jelimo, J.; Mokaya, A. Students' perspective on the impact of cleanliness of university facilities on academic achievement: A case of a public University in Kenya. Afr. J. Environ. Sci. Technol. 2018, 3, $93-99$.

70. Tome, A.; Mashiloan, T. Nurturing Learners' Awareness of Littering through Environmental Campaigns: An Action Research Approach. Eurasia J. Math. Sci. Technol. 2017, 13, 6909. [CrossRef]

71. Karkkainen, S.; Haukipuro, L.; Rummukainen, A.M.; Keinonen, T.; Simola, H. Environmental responsibility: A case study among sixth graders. Probl. Educ. 2013, 54, 22-38. [CrossRef]

72. Makonya, W. A Study of Litter Problems in Selected Secondary Schools in Bulawayo. Master's Thesis, University of South Africa, Pretoria, South Africa. [CrossRef]

73. Green Campus Initiative (GCI). University of Cape Town. 2012. Available online: http://blogs.uct.ac.za/UCTGCI/ (accessed on 12 November 2020).

74. Ampofo, A. Implications of Poor Waste Disposal Management Practices on Senior High Schools Within the Wa Municipality 2018. Available online: https:/ /www.fepbl.com/index.php/ijarss/article/view/156 (accessed on 12 February 2019).

75. Starovoytova, D. Solid Waste Management at a University Campus: Waste Generators, Current Practices, and Compliance with relevant-law-provisions. Environ. Earth Sci. 2018, 8, 6.

76. Katherine, J. The Effects of Replacing Dispersed Trash and Recycling Bins with Integrated Waste Receptacles on the Accuracy of Waste Sorting in an Academic Building. Master's Thesis, Faculty of The Graduate College, Western Michigan University, Kalamazoo, MI, USA, 2012. Available online: https:/ / pdfs.semanticscholar.org/0981/71a9b0c0bafb60abeb1630de35adaf65f979 .pdf (accessed on 30 December 2019).

77. Duffy, S.; Verges, M. It Matters a Hole Lot: Perceptual Affordances of Waste Containers Influence Recycling Compliance. Environ. Behav. 2009, 41, 741-749. [CrossRef]

78. Feiyu, C.; Hong, C.; Meifen, W.; Shanshan, L.; Ruyin, L. Research on the Driving Mechanism of Waste Separation Behavior: Based on Qualitative Analysis of Chinese Urban Residents. Int. J. Environ. Res. 2019, 16, 1859.

79. Alam, P.; Ahmade, K. Impact of Solid Waste on Health and the Environment. Int. J. Sustain. Dev. Green Econ. $2013,2,165-168$.

80. Limon, M.R.; Villarino, C.B.J. Knowledge, attitudes and practices on household food waste: Bases for formulation of a recycling system. Glob. J. Environ. Sci. 2020, 6, 323-340.

81. Bom, U.B.; Belbase, S.; Bibriven Lila, R. Public Perceptions and Practices of Solid Waste Recycling in the City of Laramie in Wyoming, U.S.A. Recycling 2017, 2, 11. [CrossRef] 
82. Philipsen, Y. Factors Influencing Students' Intention to Recycle. Master's Thesis, School of Management and Governance, University of Twente, Enschede, The Netherlands, 2015.

83. Emanuel, R.; Adams, J. College students' perceptions of campus sustainability. Int. J. Sustain. High. 2011, 12, 79-92. [CrossRef]

84. Pike, L.; Shannon, T.; Lawrimore, K.; McGee, A.; Taylor, M.; Lamoreaux, G. Science education and sustainability initiatives. Int. J. Sustain. High. 2003, 3, 12. [CrossRef]

85. Abila, B.; Kantola, J. The Perceived Role of Financial Incentives in Promoting Waste Recycling. Empirical Evidence from Finland. Recycling 2019, 4, 4. [CrossRef]

86. Thorgesen, J. Monetary incentives and Recycling: Behavioral and Psychological Reactions to a Performance-Dependent Garbage Fee. J. Consum. Policy 2003, 26, 197-228.

87. Vivian, V.W.Y.; Tam, C.M. Waste reduction through incentives: A case study. Build. Res. Inf. 2008, 36, 37-43. [CrossRef]

88. Alessandro, B.; Natalia, M.; Piovesan, M. Do Not Trash the Incentive! Monetary Incentives and Waste Sorting. Scand. J. Econ. 2011, 117, 1204-1229. [CrossRef]

89. Owojori, O.; Edokpayi, J.; Ratshalingwa, M.; Odiyo, J. Characterisation, recovery and recycling potential of solid waste in a university of a developing economy. Sustainability 2020, 12, 5111. [CrossRef]

90. Negrusa, A.; Toader, V.; Sofica, A.; Tutunea, M.; Rus, R. Exploring gamification techniques and applications for sustainable tourism. Sustainability 2015, 7, 11160-11189. [CrossRef] 